\title{
KAMPANIA POLSKA 1939 ROKU. PRZEGLĄD KONCEPCJI I SPOSOBÓW JEJ PREZENTACJI W HISTORIOGRAFII I EDUKACJI HISTORYCZNEJ XX WIEKU
}

\author{
Anita Młynarczyk-Tomczyk (D) http://orcid.org/0000-0002-7116-4198 \\ Uniwersytetu Jana Kochanowskiego w Kielcach
}

\author{
ABSTRACT \\ THE POLISH CAMPAIGN OF 1939 IN HISTORIOGRAPHY \\ AND HISTORICAL EDUCATION OF THE 20 ${ }^{\text {TH }}$ AND $21^{\text {ST }}$ CENTURIES, \\ IN ITS SELECTED ASPECTS
}

The article is part of a publication series devoted to the terminological and historiographic aspects of the Polish campaign of 1939. A completely new approach to this important event is the focus on its presence in historical education of the $20^{\text {th }}$ and $21^{\text {st }}$ century. The Polish Campaign of 1939 has held a special place in the historiographic narrative and school curricula alike. Its depictions both academic and popular-scientific - have been and still remain compatible with each other. At certain times however - especially during the ideological assault of the $1950 \mathrm{~s}$ - historical education diverged from historiography, creating an anti-German and pro-Soviet image. After 1989, the narrative of the Polish campaign of 1939 changed significantly and the "forgotten threads" were also introduced. This event still occupies a leading place in the so-called historical policy. It has also been put on a pedestal in historical education of school students, although for a period of several years in the early $21^{\text {st }}$ century it was largely absent due to the limited number of topics from the recent history included in the school curriculum.

Keywords: The Polish campaign of 1939, terminology, historiography, popularization, education, memory.

Słowa kluczowe: kampania polska 1939 roku, terminologia, historiografia, popularyzacja, edukacja, pamięć. 


\section{ASPEKT TERMINOLOGICZNY}

Do jednych z najczęściej używanych i zakorzenionych w historiografii sformułowań określających wydarzenia, jakie rozegrały się na ziemiach polskich we wrześniu i w październiku 1939 roku, należy termin „kampania wrześniowa”'. Określenie to utrwaliło się w historiografii i w świadomości historycznej Polaków już w pierwszych latach po II wojnie światowej². Sformułowanie kampania wrześniowa wpisało się w nurt komunistycznej propagandy sowieckiej i PRL-owskiej, pragnącej wyciszyć znaczenie polskiego oporu na rzecz dalszej kontynuacji walk przez siły związane z Armią Czerwoną ${ }^{3}$. W tym czasie pieczę nad publikacjami przejął urząd cenzury. Cenzura była również wszechobecna w innych strefach nauki, kultury i sztuki ${ }^{4}$.

Po przełomie październikowym 1956 roku, który przyniósł nowy etap badań w polskiej historiografii wojskowej ${ }^{5}$, zaproponowano nowy termin - „wojna wyzwoleńcza narodu polskiego”. Opór, który Polska stawiała III Rzeszy, zgodnie z „marksistowską teorią wojen” zaliczono do „sprawiedliwych”. Ze strony Niemiec przypisano jej „niesprawiedliwy, imperialistyczny i ludobójczy charakter”. Tytuł „Wojna wyzwoleńcza narodu polskiego" nadano sesji naukowej, która odbyła się z okazji 15-lecia ludowego Wojska Polskiego (dalej: LWP) w Warszawie 4-6 października 1958 roku. Zgromadziła ona licznych historyków cywilnych i wojskowych oraz uczestników omawianych wydarzeń. Materiały z sesji ukazały się drukiem w 1959 roku$^{8}$. Jej pokłosiem stała się też praca zbiorowa pt. Wojna wyzwoleńcza narodu polskiego w latach 1939-1945. Węzłowe problemy9. Ukazała się ona w 1963 roku z okazji 20-lecia LWP pod auspicjami powstałego w 1959 roku Wojskowego Instytutu Historycznego

${ }^{1}$ Szerzej zob. W. Rezmer, Problem terminologiczny: kampania wrześniowa - wojna obronna Polski-kampania polska, „Przegląd Historyczno-Wojskowy” 2009, nr 3, s. 118-120.

${ }^{2}$ Ibidem, s. 121.

${ }^{3}$ Ibidem.

${ }^{4}$ Z. Romek, Cenzura w PRL, Analiza zjawiska, red. Z. Romek, K. Kamińska-Chełmniak, Warszawa 2017, s. 29. Urząd cenzury pod nazwą Centralne Biuro Kontroli Prasy powstał 19 I 1945 r. Od 15 XI 1945 r. funkcjonował jako Główny Urząd Kontroli Prasy Publikacji i Widowisk. Zob. idem, Cenzura a nauka historyczna w Polsce 1944-1970, Warszawa 2010, s. 37.

${ }^{5}$ Lata 1956-1970 określone zostały w literaturze naukowej jako okres intensywnego rozwoju polskiej historiografii wojskowej zgodnie z założeniami materializmu dziejowego. Studia z dziejów polskiej historiografii wojskowej, t. 1, red. B. Miśkiewicz, Poznań 1975, s. 33.

${ }^{6}$ W. Rezmer, Problem terminologiczny, s. 123; B. Miśkiewicz, Studia z dziejów, s. 33.

7 T. Rawski, Z. Stąpor, J. Zamoj ski, Wojna wyzwoleńcza narodu polskiego w latach 1939-1945. Węzlowe problemy, Warszawa 1963, s. 129.

${ }^{8}$ Tom zawierał materiały sesji (tekst próbnej syntezy „Wojna wyzwoleńcza narodu polskiego w latach 1939-1945", 14 referatów wygłoszonych na sesji oraz głosy w dyskusji). M. Getter, Wrzesień 1939 w ksiązce, prasie i filmie. Poradnik Bibliograficzny, słowo wstępne W. B artoszew ski, Warszawa 1964, s. 2-3. Zob. Sesja naukowa poświęcona wojnie wyzwoleńczej narodu polskiego 1939-1945 (4-6 X 1958). Materiaty, kol. red. S. Arnold i in., Warszawa 1959.

9 P. Stawecki, Jeszcze raz w sprawie określenia „, wojna obronna Polski 1939”, „Przegląd Historyczno-Wojskowy” 2010, nr 1, s. 163; T. Rawski, Z. Stąpor, J. Zamojski, Wojna wyzwoleńcza, s. XIX, 755. 
$\left(\right.$ dalej: WIH ${ }^{10}$. Miała ona być w zamyśle syntezą wysiłku zbrojnego Polski w II wojnie światowej ${ }^{11}$. Piętno czasu przejawiające się w zawłaszczeniu historii najnowszej przez historyków partyjnych sprawiło, że była to pozycja ograniczona merytorycznie (bez wojny z ZSRR i okupacji sowieckiej), z wieloma błędnymi pojęciami, o czym będzie mowa w dalszej części artykułu.

Pod koniec lat 60. XX wieku do obiegu naukowego i podręczników szkolnych wprowadzono dodatkowo termin „wojna obronna Polski w 1939 roku”"12. Taką terminologię zaproponowano podczas kolejnego sympozjum, zorganizowanego przez WIH w 25-lecie wybuchu II wojny światowej (4-5 września 1964 roku) ${ }^{13}$. Tytuł „Wojna obronna Polski w 1939 roku” nadano również wydawanej od 1969 roku (z okazji 30. rocznicy wydarzeń z 1939 roku) wielotomowej bibliografii ${ }^{14}$. Na określenie wydarzeń z jesieni 1939 roku używano w niej zamiennie zwrotów: „wojna obronna Polski” (tytuł) i „kampania wrześniowa” (przy nazewnictwie rozdziałów) ${ }^{15}$. Ostatecznie do 1992 roku opublikowanych zostało sześć wydawnictw bibliograficznych obejmujących dorobek do lat 1988-1989 ${ }^{16}$. Termin „wojna obronna Polski” wprawdzie od końca lat 60 . XX wieku był dominujący, nie wyeliminował on jednak dotychczas obowiązującego określenia: „kampania wrześniowa”" ${ }^{17}$ czy „wojna wyzwoleńcza narodu polskiego"18.

Przywołane terminy „kampania wrześniowa” i „wojna obronna Polski 1939 roku” zostały przedmiotem polemiki po 1989 roku, kiedy polska historiografia stała się suwerenna i wolna od cenzury. Zaproponowano wówczas termin „emocjonalnie naturalny i prawdziwy merytorycznie - kampania polska 1939 roku"19. Określenie to od

10 P. Stawecki, Jeszcze raz w sprawie określenia, s. 162-163.

11 Ibidem, s. 163; zob. też T. Rawski, Z. Stąpor, J. Zamojski, Wojna wyzwoleńcza, s. XIX, 755. Autorzy, stosując ,marksistowskie założenia ideowe i metodologiczne”, przybliżyli wysiłek zbrojny narodu na szerokim tle wojny światowej. M. Getter, Wrzesień 1939, s. 2.

12 Zob. m.in. Wojna obronna Polski 1939. Wybór źródeł, pod kier. E.J. Kozłowskiego, Warszawa 1968. Do podręczników określenie to zostało wprowadzone w 1974 r. (A.L. Szcześniak, Historia dla klasy VIII, Warszawa wyd. 1, 1974 r.) i funkcjonowało jeszcze w latach 90. XX w. T. Glubiński, $H i$ storia 8. Trudny wiek XX, wyd. 1, Warszawa 1992; T. Siergiejczyk, Dzieje najnowsze 1939-1945. Historia dla szkót średnich (klasa IV liceum ogólnokształcącego oraz klasa III technikum i liceum zawodowego), Warszawa 1991.

13 P. Stawecki, Jeszcze raz w sprawie okré́lenia, s. 164.

14 Wojna obronna Polski w 1939 r. Bibliografia (wydanie II rozszerz.), Warszawa 1971, k. XI. Dwa lata później wydano rozszerzoną jej wersję, m.in. o pozycje wydane z okazji 30. rocznicy wydarzeń z IX i X 1939 r. Ibidem.

15 Ibidem, k. III-IX.

16 Oprócz wcześniej wymienionych były to: Wojna obronna Polski w 1939 r., Warszawa 1992.

17 Przykład stanowi nazewnictwo zaprezentowane we wspomnianej bibliografii: Wojna obronna Polski w 1939 r, k. III-IV. Posługiwano się też terminem „kampania wrześniowa” w wielu publikacjach naukowych m.in. J.A. Radomski, Kampania wrześniowa na Ziemi Sadeckiej, Nowy Sącz 1971; Z. Kosztyła, Kampania wrześniowa 1939 na Białostocczyźnie: Nowogród, Łomża, Wizna, Tykocin, Białystok 1971.

18 Bibliografia wojny wyzwoleńczej narodu polskiego 1939-1945. Problematyka wojskowa. Materiały z lat 1939-1967, oprac. K. Szczepańska, B. Zielińska, Warszawa 1973; Wojna wyzwoleńcza narodu polskiego w latach 1939- 1945, red. B. Skrzypak, Warszawa 1967.

19 W. Rezmer, Problem terminologiczny, s. 123. 
początku XXI wieku zajmuje coraz wyraźniejszą pozycję w polskiej historiografii ${ }^{20}$. Warto dodać, że pojęcie kampanii polskiej poprzedziły jeszcze inne określenia odbiegające od dominującej w historiografii PRL nomenklatury: kampanii wrześniowej i wojny obronnej, a mianowicie „wojna polska” i „kampania jesienna”. Wprowadził je do obiegu naukowego Leszek Moczulski (dziennikarz, publicysta, działacz polityczny, z zawodu również historyk i geopolityk, współtwórca Ruchu Obrony Praw Człowieka i Obywatela) w swej pracy Wojna polska. Rozgrywka dyplomatyczna w przededniu wojny i działania obronne we wrześniu - październiku 1939 (wyd. 1972). Pierwsze wydanie tej książki ukazało się w krótkim okresie odwilży po wydarzeniach 1970 roku i prawie cały nakład został natychmiast sprzedany. Po interwencji ambasady radzieckiej szybko wycofano ją z księgarń, bibliotek i przeznaczono na przemiał $^{21}$. Moczulski nadał swej pracy tytuł „wojna polska”, zaznaczając, że pierwszoplanową rolę odegrały przy tym nie czynniki historiograficzne ani militarne, ale mentalne. Jak podkreślał, „Wrzesień był dla nas i pozostanie chyba na zawsze «wojną polską»" ${ }^{22}$. Terminy „wojna polska” i „kampania jesienna” na trwałe weszły do kolejnych wydań publikacji Moczulskiego ${ }^{23}$.

Niewątpliwie mimo upływu kilkudziesięciu lat dyskusja w sprawie kwestii zdefiniowania wydarzeń, które rozegrały się na obszarze II RP i terenach przyległych we wrześniu i w październiku 1939 roku, toczy się nieustannie ${ }^{24}$. Na początku XXI wieku tytuł Kampania wrześniowa 1939 nadano najobszerniejszej bibliografii poświęconej temu wydarzeniu. Była to uaktualniona i rozbudowana wersja bibliografii z lat 1969-199225. Według danych z Centralnej Biblioteki Wojskowej z 1 lutego 2014 roku kampanii polskiej 1939 roku dotyczyły 14652 pozycje $^{26}$. Wśród nich wiele

${ }^{20}$ C. Grzelak, Kampania polska 1939 roku: poczatek II wojny światowej, Warszawa 2005; W. Rezmer, Armia „Pomorze” w kampanii polskiej 1939 roku. Bitwa nad Bzura, Bydgoszcz 2004.

${ }^{21}$ C. Grzelak, Kampania polska 1939 roku w ojczystej historiografii, „Bellona” 2016, nr 4, s. 139; L. Moczulski, Wojna polska, Warszawa 2009 [nota wydawnicza], b.p.s. Zob. też: https://www.biblionetka.pl/book.aspx?id=81457 [Nota wydawcy. Bellona, 2009] [dostęp: 15 V 2020 r.].

${ }^{22}$ L. Moczulski, Wojna polska. Rozgrywka dyplomatyczna w przededniu wojny i działania obronne we wrześniu - październiku 1939, Poznań 1972, s. 14.

${ }^{23}$ Przed kolejnymi wydaniami jej autor aktualizował niektóre fragmenty swej pracy, a po $1990 \mathrm{r}$. dodał to, co w wolnej Polsce można było już jawnie pisać. Poszerzył też bazę źródłową. Ł. Męczykowski, ,Wojna polska 1939” - recenzja i ocena, https://histmag.org/Leszek-Moczulski-Wojna-polska-1939-recenzja-3797/ [dostęp: 15 V 2020 r.].

${ }^{24}$ W. Rezmer, Problem terminologiczny, s. 117. Rezmer określenie „kampania wrześniowa” uznał za krzywdzące w stosunku do obrońców Helu i żołnierzy walczących pod Kockiem, ibidem. Również określenie „wojna obronna” Polski uznał za nieprecyzyjne, ibidem, s. 121. Termin ten stał się przedmiotem dyskusji naukowej, znalazł zarówno przeciwników, jak i zwolenników. Paweł Wieczorkiewicz odniósł się do niego w sposób pejoratywny. Z kolei związany z WIH Piotr Stawecki podjął się jego obrony. Zob. P. Stawecki, W sprawie terminu „,wojna obronna Polski”, „Przegląd Historyczno-Wojskowy” 2007, nr 1, s. 205-206; idem, Jeszcze raz w sprawie określenia, s. 161-168.

${ }^{25}$ Kampania wrześniowa 1939. Bibliografia, t. 1-2, wstęp K. Komorow ski; oprac. I. Kowalska, I. Sawicka; współpr. W. Henzel, E. Pawińska, K. Świerczyńska, Warszawa 2000-2002; Kampania wrześniowa 1939. Bibliografia, t. 3, red./oprac. A. Koc [et al.], Warszawa 2009.

${ }^{26}$ C. Grzelak, Kampania polska, s. 136. 
prac naukowych, zawierających w tytule terminy „kampania wrześniowa”27, „,wojna obronna Polski" ${ }^{28}$ czy ,polski wrzesień” ${ }^{29}$. Terminy dotyczące wydarzeń z jesieni 1939 roku traktowane są więc w najnowszej historiografii wymiennie. Niewątpliwie jednak rację mają ci badacze, a wśród nich wspomniany profesor Waldemar Rezmer, którzy podkreślają, że sprowadzenie kampanii polskiej 1939 roku tylko do września umniejsza fakt obrony ojczyzny jeszcze w październiku (Kock, obrona Helu).

\section{ZWIĘZŁY PRZEGLĄD HISTORIOGRAFII POLSKIEGO WYSIŁKU MILITARNEGO Z 1939 ROKU}

W krótkim przeglądzie historiografii kampanii polskiej 1939 roku zwrócono uwagę na zasadnicze kierunki badań i ich wyniki przede wszystkim w postaci publikacji książkowych, jak i - w zarysie - dokonano próby przeglądu historiozofii jej dziejów, które owe kompendia prezentowały. Niniejszy przegląd, z założenia nakreślony szkicowo, stanowi próbę ogólnego spojrzenia na dorobek polskiej historiografii PRL i zestawienia go z przemianami po 1989 roku. Rok ten, przełomowy, stanowił bowiem w Polsce swego rodzaju cezurę zarówno w badaniach historycznych, jak i w ich upowszechnianiu ${ }^{30}$.

Od zakończenia II wojny światowej jej historia stanowiła istotny element tak zwanej polityki historycznej ${ }^{31}$. Była ona jedną z ważniejszych aktywności partii (PZPR) w zakresie budowy zgodnego z jej linią, właściwego historycznego przekazu. Wykorzystanie nastrojów obywateli pamiętających wojnę i okupację nie było trudne i doskonale służyło realizacji partykularnych interesów ówczesnych władz ${ }^{32}$. Po wydarzeniach z 1989 roku narracja została istotnie zmieniona i uzupełniona o ,zapomniane

27 A. Horak, Kampania wrześniowa w oświetleniu niemieckim, Warszawa 2005; Kampania wrześniowa 1939 roku na ziemi jordanowskiej. Materialy z sympozjum naukowego, Jordanów, 3 IX 2003 r.

${ }_{28}$ A. Grzywacz, Wojna obronna Polski 1939 roku w relacji polskiego sztabowca, ,Zeszyty Historyczne” 1997, z. 121, s. 3-22; Z. Bartkowski, Pogoda września a wojna obronna Polski, „Przegląd Geofizyczny" 1999, z. 3, s. 153-161.

${ }_{29}$ Polski wrzesień 1939 r. - wojna na dwa fronty. Materiaty Międzynarodowej Konferencji Nauko$w e j$, red. A. Felchner, Piotrków Trybunalski 1999.

${ }^{30}$ M. Ney-Krwawicz, Wrzesień 1939 roku w historiografii polskiej ostatniego dwudziestolecia, [w:] Spojrzenie na polski wrzesień, red. T. Kondracki, Warszawa 2011, s. 9-10.

${ }_{31}$ Związek historii z polityką definiowany jest jako polityka historyczna. Obie sfery pozostają ze sobą w stałym związku. R. Stobiecki, Historycy wobec polityki historycznej [w:] Pamięć i polityka historyczna. Doświadczenia Polski i jej sąsiadów, red. S.M. Nowinowski, J. Pomorski, R. Stobiecki, Łódź 2008, s. 175.

${ }^{32}$ Rocznica zbiegała się z początkiem roku szkolnego. Obok kombatantów (nie wszystkich) młodzież była najczęściej „tłem” rocznicowych uroczystości. Wrześniowa rocznica wyraźnie dzieliła wówczas kraj i emigrację, Polaków z różnych formacji wojskowych i politycznych z różnych wojennych formatów. J. Chrobaczyński, „Nie okryt się niesławą naród polski”. Społeczne aspekty września 1939 roku, Kraków 2002, s. 145. 
wątki" (białe plamy), ale dostosowana do nowych politycznych warunków ${ }^{33}$. Jak podkreśla się w literaturze naukowej, wydarzenia związane z wojną i okupacją były i pozostają nadal jednymi z najbardziej utrwalonych w pamięci zbiorowej Polaków ${ }^{34}$.

W okresie PRL, gdy żyło wielu uczestników wojny, zarówno wojskowych, jak i cywilów, którzy wychowywali w jej tradycji również swe dzieci i wnuki, literatura dotycząca września 1939 roku cieszyła się niesłabnącym zainteresowaniem. Starsze pokolenie pragnęło wyrobić sobie pełniejszy pogląd na te wydarzenia, konfrontując własne przeżycia i doświadczenia z ocenami historyków czy pamiętnikarzy. Młodzież, nieposiadająca już osobistego stosunku do kampanii polskiej 1939 roku oraz okupacji, też interesowała się tym okresem ze względu na losy swych bliskich ${ }^{35}$. Było to pierwsze pokolenie urodzone tuż po wojnie (lata 1945-1950). Ze względu na młody wiek miało ambiwalentny stosunek do stalinizacji ${ }^{36}$. Przeszło natomiast pełny kurs systemu szkolnego, nastawionego na bliskie potrzebom partii oddziaływanie wychowawcze, ideowe i propagandowe.

Kampania polska 1939 roku znalazła odzwierciedlenie w historiografii okresu zaraz po klęsce, w publikacjach konspiracyjnych 1939-19447 , a następnie w wydawnictwach typu dokumentalnego, twórczości literackiej i syntetycznych ujęciach tej tematyki $^{38}$. Jak jednak zauważył Moczulski, na pracach tych zaciążyły dwa ujemne czynniki. Pierwszym z nich było podporządkowanie prac i ich wymowy bezpośrednim potrzebom politycznym. Drugim ujemnym bodźcem, który „wycisnął poważniejsze piętno na literaturze”, a którego „działanie” - jak zauważał Moczulski - „słabnie znacznie wolniej” - była „psychoza klęski”39. Oba wyżej wymienione czynniki przyczyniły się do ,zamazania prawdy historycznej, do zastąpienia jej bogatego i skomplikowanego obrazu uproszczonymi, czarno-białymi lub wyłącznie czarnymi schematami”"40.

Pierwsze syntetyczne ujęcie kampanii polskiej 1939 roku ukazało się w 1946 roku. Jego autorem był Jerzy Kirchmayer - w czasie kampanii polskiej oficer Sztabu Armii „Pomorze”, w 1948 roku przeniesiony w stan spoczynku, aresztowany, więziony do 15 października 1955 roku, zrehabilitowany w kwietniu 1956 roku $^{41}$. W dziele tym, „obejmującym całokształt działań wojennych, które stały się wstępem do drugiej

${ }^{33}$ K. Kącka, ,Mapa pamięci”. Jak upamiętnia się w Polsce II wojnę światowa, „Wiadomości Historyczne z Wiedzą o Społeczeństwie" 2017, nr 3, s. 4.

${ }^{34}$ Eadem, ,,Mapa pamięci”, s. 4; K. Ruchniewicz, Pamięć historyczna Polaków, „Śląski Kwartalnik Historyczny Sobótka” 2005, nr 2, s. 214.

${ }_{35}$ Od autora [w:] M. Getter, Wrzesień 1939, k. III.

${ }^{36} \mathrm{~K}$. Kersten do podstawowych jego cech zaliczyła: charakter systemowy; totalitaryzm rozumiany jako totalna kontrola, totalnymi środkami, sprawowana nad totalnie organizowanym społeczeństwem, dla totalnych celów ideologicznego państwa - partii. Zob. K. Kersten, Pisma rozproszone, wybór i przygotowanie do druku T. Szarota i D. Libionka, Torun 2005, s. 388. Za apogeum stalinowskiego systemu przyjmuje się lata 1949-1955. Ibidem, s. 397.

37 W. Bartoszews ki, Stowo wstępne [w:] M. Getter, Wrzesień 1939, k. VII.

${ }^{38}$ Ibidem.

${ }^{39}$ L. Moczulski, Wojna polska, s. 555 (ibidem, wyd. Lublin 1990, s. 558).

40 Ibidem.

${ }^{41}$ S. Płoski, Generał Jerzy Kirchmayer. Najnowsze dzieje Polski: materiały i studia z okresu II wojny światowej 1959, t. 3, s. 241. 
wojny światowej i tragiczną katastrofą złudzeń, w których przez dwadzieścia lat żyła odrodzona Polska” ${ }^{2}$, na tle ,zupełnie do wojny nieprzygotowanego wojska” polskiego przybliżył wojsko niemieckie ,gotujące się przez 20 lat do wojny i rewanżu" Wytykał odrzucenie możliwości „współdziałania z ZSRR”, za co odpowiedzialność zrzucił na rząd polski ${ }^{44}$. Polski „plan wojny” nazwał „gmachem bez fundamentów”, który nie mógł wytworzyć siły skutecznie przeciwstawiającej się napaści ${ }^{45}$.

Przebieg działań również przedstawiony został w czarnych, pesymistycznych kolorach. Świadczyły o tym następujące tytuły rozdziałów: „Bitwa graniczna 1-3 IX”; „Rozerwanie polskiego frontu - 4-6 IX”; „Katastrofa - 7-17 IX”; „Koniec walki 18 IX - 5 X"46. O 17 wrześniu i wkroczeniu Armii Czerwonej Kirchmayer nie wspomnia ${ }^{47}$. Zawarł jedynie lakoniczną informację o tym, że działania niemieckie w końcowym okresie kampanii zmierzały do przerwania walki w obszarze na wschód od Wisły z powodu początkowego zamiaru „oddania wojsku radzieckiemu obszaru aż po Wisłę"48. Ocena wydarzeń z września i października 1939 roku była jednak stonowana. Autor zauważał, że kampania miała wielkie ogólnoświatowe znaczenie wojskowe i polityczne ${ }^{49}$. Nawoływał, by „wyciągnąć wnioski z doświadczeń klęski wrześniowej i na tej podstawie zorganizować nową Polskę" ${ }^{50}$. Zainteresowanie kampanią polską zaowocowało cennymi (jak na tamten czas), choć ograniczonymi dominującym wpływem partii i cenzurą - przedsięwzięciami wydawniczymi. Tak też było w przypadku pracy generała Kirchmayera.

W okresie stalinizmu kampanię polską 1939 roku traktowano jednostronnie, jako klęskę zawinioną przez sanację. Krytyka rządu przedwrześniowego była dominująca w historiografii PRL ${ }^{51}$, chociaż, co należy podkreślić, był to rząd formalny, oparty na konstytucji z 23 kwietnia 1935 roku. Jej antydemokratyczne postanowienia i sposób, w jaki została uchwalona, wprawdzie do dziś jeszcze budzą wśród jej badaczy uzasadniony sprzeciw ${ }^{52}$. Nie ulega jednak wątpliwości, że umożliwiała ona ciągłość praw-

${ }^{42}$ J. Kirchmayer, Kampania wrześniowa, Warszawa 1946. Praca pisana w czasie okupacji i ukończona zaraz po wojnie krytykowana była za braki i błędy źródłowe. M. Getter, Wrzesień 1939, s. 3.

${ }_{43}$ J. Kirchmayer, Kampania, s. 30.

44 Ibidem, s. 14.

45 Ibidem, s. 53

${ }^{46}$ Ibidem, s. 79-209.

${ }^{47}$ Wspomniał o niej autor we wstępie, przywołując pracę wydaną w Londynie w II $1941 \mathrm{r}$. autorstwa gen. dyw. Mieczysława Norwid-Neugebauera. Wskazał, że autor ten „obniżył wartość swej pracy”, usiłując ,wpoić w czytelnika przekonanie, że rozstrzygającym powodem katastrofy było przekroczenie przez wojsko radzieckie granicy polskiej w dniu 17 września [...]”, ibidem, s. 8. Piotr Stawecki podkreślał, że „tego rodzaju opinie już wówczas nie mogły być rozpowszechniane w Polsce Ludowej wobec postępującej sowietyzacji. Stąd wyniknąć mogły, jak wskazywał, represje wobec gen. Kirchmayera. P. Staw ecki, Jeszcze w sprawie, s. 162.

48 J. Kirchmayer, Kampania wrześniowa, s. 205.

${ }^{49}$ Ibidem, s. 208.

${ }^{50}$ Ibidem, s. 268.

${ }^{51}$ Wskazywano na jej faszystowski charakter. Szerzej zob. D. Górecki, Pozycja ustrojowo-prawna Prezydenta Rzeczypospolitej i rządu w ustawie konstytucyjnej z 23 kwietnia 1935 roku, Łódź 1992, s. $276-278$.

${ }^{52}$ Ibidem, s. 278. 
nokonstytucyjną i podmiotową Polski na arenie międzynarodowej, przed i po klęsce 1939 roku $^{53}$. Charakterystycznym przykładem jednostronnego spojrzenia na rząd przedwrześniowy była powieść historyczna Jerzego Putramenta (od 1946 r. członka KC PZPR) pt. Wrzesień. Już jej tytuł stanowił próbę umniejszenia wysiłku polskiego żołnierza, sprowadzając go tylko do jednego miesiąca - września 1939 roku. Dodatkowo w całej publikacji dominowało ujęcie szyderczo-krytyczne i jednostronny, tendencyjny przekaz ${ }^{54}$. Pierwsze jej masowe wydanie ukazało się w 1953 roku nakładem wydawnictwa MON (nakład 75 tys. egzemplarzy). W 1980 roku ukazało się jej 14. wydanie ${ }^{55}$.

Równie jednostronny i pełen zakłamań był obraz kampanii polskiej z 1939 roku, jaki zaprezentowano w całościowym ujęciu II wojny światowej, wydanym z okazji 20-lecia LWP (1963). Za klęskę poniesioną w 1939 roku w sposób jednostronny, bez uwzględnienia czynników międzynarodowych i sytuacji społeczno-gospodarczej międzywojennej Polski, obwiniano, wzorując się na historiografii lat 50. XX wieku, wyłącznie rząd sanacyjny. Zarzucano mu, że nie doprowadził w okresie międzywojennym do umocnienia i rozwoju gospodarki państwa ${ }^{56}$. Widziano tylko jeden pozytyw tego okresu: ukształtowanie się sił społecznych i politycznych, które „walcząc przeciw sanacji i jej awanturniczej polityce, reprezentowały rzeczywistą troskę o siły obronne i niepodległość Polski”"57. Miano na myśli oczywiście Komunistyczną Partię Polski ${ }^{58}$. Ubolewano, omawiając pozycję międzynarodową Polski przedwrześniowej, że „stałym motywem poczynań Polski na forum międzynarodowym była właśnie wrogość wobec Związku Radzieckiego" 59 . W ten sposób starano się wybielić winę ZSRR jako agresora wobec Polski. Oceniając historię z perspektywy czasu, wskazywano na nieprzydatność sojuszy z Francją, Wielką Brytanią czy Rumunią ${ }^{60}$. O pakcie Ribbentrop-Mołotow nie wspomniano ${ }^{61}$.

${ }^{53}$ Wskazuje się, że jej przepisy - przy tworzeniu bardzo mocno krytykowane - w praktyce okazały się dla bytu państwowego Polski i zachowania ciągłości władzy wręcz zbawienne. J.M. Majchrowski, Wstęp, Stanisław Car - Polska koncepcja autorytaryzmu, wstęp i wybór J.M. Maj chrowski, Warszawa 1996, s. 22.

${ }^{54}$ Poddano krytyce politykę międzynarodową Polski przedwrześniowej i zawarte przez nią sojusze. J. Putrament, Wrzesień. Powieść, t. 1, Warszawa 1953, s. 22; złe przygotowanie do wojny i fatalny stan armii, a winę za ten stan jednostronnie zrzucano tylko na rząd sanacyjny, ibidem, s. 62, 93, 102, 120, 153. Obarczono nawet rząd winą za pakt Ribbentrop-Mołotow, ibidem, s. 70. Na tym tle podkreślano ducha walki, jaki charakteryzował naród polski w obliczu wojny, ibidem, s. 71. Szczególną rolę przypisywano komunistom. Wyeksponowano ich udział w wojnie, zwłaszcza w obronie Warszawy, ibidem, s. 238. Kampanię polską 1939 r. określano jako „dni rozpaczy”, ibidem, s. 126, po których została „proletariacka Warszawa”, bez „przymusów, gróźb i przywilejów, zwany reżimem sanacyjnym”, ibidem, s. 236-237 i ,skierowana na wschód”, ibidem, s. 251.

${ }_{55}$ J. Putrament, Wrzesień. Powieść, t. 1, Warszawa 1980 [1953].

${ }^{56}$ T. Rawski, Z. Stąpor, J. Zamojski, Wojna, s. 36.

${ }^{57}$ Ibidem, s. 80.

${ }^{58}$ Ibidem.

${ }^{59}$ Ibidem, s. 44.

${ }^{60}$ Ibidem, s. 61-62.

${ }^{61}$ Ibidem, s. 62. 
Ocena podjętych działań obronnych z września i października 1939 roku była negatywna. Wartościując już pierwszy tydzień wojny nie miano wątpliwości, że „klęska wojenna i upadek państwa są tylko sprawą czasu" ${ }^{2}$. Eksponowano jedynie wolę walki narodu polskiego. W sposób szczególny, wpisując się w proradziecki trend, wyeksponowano „patriotyzm” komunistów ${ }^{63}$. Na omówienie działań wojennych z jesieni 1939 roku poświęcono kilkadziesiąt stron (101-127). Jednak ich wartość oceniano bardzo nisko, a klęskę przesunięto już na połowę września ${ }^{64}$. Oddając głos autorom podręcznika: „Do 16 września Niemcy osiągnęły główne cele nakreślone w planie podboju Polski. Siły wojska polskiego zostały rozbite i w większości zniszczone [...]. Iluzoryczne okazały się rachuby na pomoc sojuszników zachodnich [...]” ${ }^{65}$. „Dopełnienie klęski” widziano w opuszczeniu kraju przez prezydenta i rząd sanacyjny oraz naczelne władze wojskowe ${ }^{66}$.

Takie nakreślenie sytuacji ułatwiało wytłumaczenie przyczyn wkroczenia na terytorium Polski wojsk radzieckich 17 września 1939 roku: Była to, jak kłamliwie tłumaczono, interwencja mająca na celu „połączenie z macierzą zachodnich ziem ukraińskich i białoruskich”, która, jak dodatkowo tłumaczono, „pozwalała uchronić mieszkańców tych ziem przed okupacją hitlerowską oraz przesuwała linię nieuniknionego w przyszłości starcia z Niemcami [...]"67. Datę 17 września wpisano w proradziecki nurt i thumaczono stronniczo jako interwencję w obronie ludności zachodniej Ukrainy i Białorusi przed okupacją niemiecką. Ocena kampanii polskiej 1939 roku była jednostronna. Uznano ją, doceniając wprawdzie patriotyczną postawę całego narodu i bohaterską walkę żołnierza polskiego, za „ciężką klęskę polityczną i militarną burżuazyjno-obszarniczego państwa polskiego, a zwłaszcza jednego z najbardziej wstecznych ich ugrupowań politycznych, tzw. Sanacji $[\ldots]]^{\prime \prime 68}$.

Dopiero lata 70. XX wieku przyniosły pierwsze wyłomy w tendencyjnym przekazie dotyczącym kampanii polskiej. Mowa tu o wspomnianej publikacji L. Moczulskiego. W obliczu dotychczasowej jednostronnej krytyki rządu polskiego, który obarczano za klęskę 1939 roku, autor wziął niektórych jego przedstawicieli, między innymi ministra spraw zagranicznych Józefa Becka, w obronę. Docenił jego postawę w okresie „polityki śmiertelnego zagrożenia”, w jaki Polska weszła, odrzucając żądania Hitlera ${ }^{69}$.

Krytykowany w dotychczasowej historiografii potencjał gospodarczy Polski został przez Moczulskiego dostrzeżony. Zdawał on sobie sprawę, że mocno oddziaływała na niego ,polityka równowagi” stanowiąca „kamień węgielny” polskiej polityki zagranicznej ${ }^{70}$. Przypominał, że dawała ona czas do odbudowy i umocnienia państwa

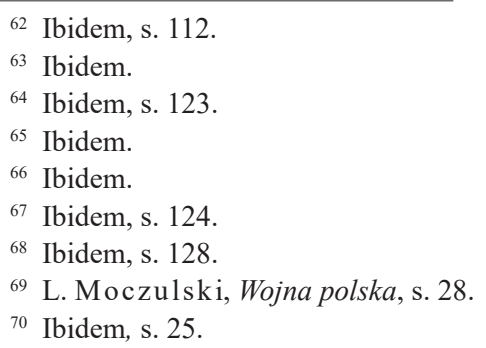


polskiego ${ }^{71}$. Choć czasu tego było mało i Polska nie zdążyła go w pełni wykorzystać, to dostrzegał osiągnięcia na przykład w produkcji polskiego przemysłu obronnego ${ }^{72}$. Dopowiadał też, że lepszy był stan potencjału wojennego pod względem rezerw ludzkich"73.

Plan operacyjny Wojska Polskiego „Z” (Zachód), opracowywany od marca 1939 roku na wypadek wojny z Niemcami, zyskał w ocenie autora miano ,interesującego i ambitnego”. Moczulski przekonywał nawet, że „w warunkach roku 1939 inny plan operacyjny, lepszy od zastosowanego w praktyce, był nie do pomyślenia"74. W ocenach kampanii polskiej zabrakło, co było novum, umniejszania roli obrony Polski w 1939 roku $^{75}$.

Fragment poświęcony dacie 17 września 1939 roku był daleki od dotychczasowego przekazu i z pewnością nie mógł zyskać akceptacji ambasady radzieckiej, która przypomnijmy - przyczyniła się do szybkiego wycofania publikacji Moczulskiego z obiegu. Mowa w książce o rozpoczętym 17 września marszu armii radzieckiej na Zachód i o jego „olbrzymich” skutkach politycznych ${ }^{76}$. Przypomniano też o rozmowach niemiecko-radzieckich $\mathrm{w}$ sprawie utworzenia satelickiego państwa polskiego i fiasku tych rozmów, na skutek sprzeciwu Stalina, który obawiał się „włączenia Polski w wyłączną orbitę Rzeszy" 77.

W ocenach kampanii polskiej po raz pierwszy w historiografii powojennej pojawił się optymistyczny ton. Już tytuł rozdziału: „Klęska i zwycięstwo” sugerował stanowisko autora w kwestii oceny polskiego wysiłku militarnego z 1939 roku. Po szczegółowym przybliżeniu, na kilkuset stronach (197-520), poszczególnych faz kampanii polskiej, Moczulski przekonywał, że „Przegrana nie może [...] stanowić głównego miernika oceny" "78. Autor dostrzegał, że ,armia polska popełniła wiele, nawet bardzo wiele błędów i wykazała nie mniejszą ilość braków", ale w jego ocenie „wojsko polskie zdało wyjątkowo trudny egzamin kampanii dobrze, a może bardzo dobrze" 79 . Autor zauważał również, powielając dotychczasowe głosy, że w trakcie kampanii polskiej „doszło do nieznanej wcześniej w historii integracji całego społeczeństwa”. Wskazywał jednak, jako pierwszy, jej ważną rolę w kształtowaniu świadomości narodowej Polaków i modelowaniu integracji całego społeczeństwa. Jak podkreślał: „Rok 1939 [...] stał się zarazem ostatnim i ostatecznym etapem porozbiorowego zjednoczenia narodu" $"$.

Autorem kolejnych publikacji odbiegających od tendencyjności w przedstawianiu kampanii polskiej był badacz genezy i wybuchu II wojny światowej Tadeusz

\footnotetext{
71 Ibidem, s. 26.

72 Ibidem, s. 90.

33 Ibidem, s. 91.

74 Ibidem, s. 108.

75 Ibidem, s. 486.

76 Ibidem, s. 487-488.

77 Ibidem, s. 489-490.

78 Ibidem, s. 524.

79 Ibidem.

80 Ibidem, s. 529.
} 
Jurga. Ramy niniejszego artykułu nie pozwalają na głębszą analizę dorobku tegoż autora. Należy jednak podkreślić, że badacz ten, w dobie fermentu politycznego lat 80. XX wieku, w jednej ze swych publikacji ${ }^{81}$ powielił ocenę kampanii polskiej zapoczątkowaną przez Moczulskiego. Postawę autora wobec tego wydarzenia dobrze odzwierciedla konkluzja: „,bilans nie tylko tragiczny”82.

Obraz kampanii polskiej 1939 roku, jaki zaproponowali Moczulski oraz Jurga, był bliski współczesnemu ${ }^{83}$. Chociaż historiografia ostatnich lat dotycząca kampanii polskiej 1939 roku wymaga oddzielonego zbadania i refleksji ${ }^{84}$, to niewątpliwie można przybliżyć pewne symptomy kontynuacji i dyskontynuacji badań w tym zakresie. Novum stanowi pogłębienie studiów nad polskim planem wojskowym. W świetle dokumentów i relacji ocenia się, że „16 września Wojsko Polskie liczyło jeszcze niemal połowę stanów początkowych, choć ich położenie było bardzo trudne" ${ }^{" 85}$. Siły te - jak wskazuje się dzisiaj ,„...] mogły z powodzeniem stawić opór przez dłuższy czas armii niemieckiej, gdyby się rozpoczęła ofensywa zachodnich sojuszników". To dopiero 17 września, co było przemilczane w okresie zależności państwa polskiego od ZSRR, sytuacja militarna Polski zmieniła się diametralnie w wyniku wtargnięcia nowego agresora ${ }^{86}$.

W ocenach polskiej kampanii 1939 roku przytacza się niezwykle wysoki bilans strat ludzkich oraz dóbr materialnych i kulturalnych ${ }^{87}$. Podkreśla się jednak doniosłe znaczenie kampanii polskiej 1939 roku dla dalszych losów II wojny światowej ${ }^{88}$. Niewątpliwie ten obraz zasadniczo różni się od dominującego do 1989 przekazu dotyczącego wydarzeń z września i października 1939 roku (choć przypomnijmy, że pierwsze wyłomy od oficjalnej propagandy pojawiły się już w latach 70 . XX w.) W najnowszej historiografii opór polskiego żołnierza w kampanii polskiej urósł do rangi heroizmu. Do dwóch czynników, które zaważyły na jej tragicznym losie, zalicza się przede wszystkim brak pomocy ze strony państw zachodnich i nóż w plecy, który został wbity 17 września.

Rok 1989 stanowił niewątpliwie przełomową datę w historiografii kampanii polskiej 1939 roku, wprowadzając dyskusję nad terminologię z nią związaną, a także

${ }^{81}$ T. Jurga, Wojna obronna Polski w 1939 r. [w:] Wojna i okupacja na ziemiach polskich, red. W. Góra, Warszawa 1984, s. 7-34. Warto dodać, że we wcześniejszym opracowaniu zbiorowym Wojna obronna Polski 1939 r. 1980 [1971, 1979], opracowanym pod patronatem Ministerstwa Obrony Narodowej, w której rozdziały dotyczące kampanii polskiej opracował T. Jurga, dominował jednostronny przekaz, m.in. w odniesieniu do rządu sanacyjnego i daty 17 IX 1939 r., zob. Wojna obronna Polski 1939 r. Polski Czyn zbrojny w II wojnie światowej, oprac. M. Cieplewicz, T. Jurga, E. Kozłowski [et al.], red. E. Kozłow ski, Warszawa 1979, s. 243, 289, 291, 305, 637-638.

${ }^{82}$ T. Jurga, Wojna obronna Polski w 1939 r., s. 32.

${ }^{83}$ C. Grzelak, E. Kozłow ski, Polski wrzesień 1939. początek drogi w obronie wolności i niepodległości, Warszawa 1994, s. 18-21.

${ }^{84}$ Wstępnie okresem tym zająl się M. Ney-Krwawicz, Wrzesień 1939 roku w historiografii, s. 9-21.

${ }^{85}$ C. Grzelak, E. Kozłowski, Polski wrzesień, s. 35.

${ }^{86}$ Ibidem, s. 47.

${ }^{87}$ Ibidem, s. 72.

${ }^{88}$ Ibidem, s. 73. 
badania nad poszczególnymi jej fazami, na nowe wolne od służebności wobec ZSRR tory. Spowodowało to likwidację wielu zakłamań, między innymi dotyczących potencjału polskiej armii i 17 września 1939 roku.

\section{OBRAZ KAMPANII POLSKIEJ 1939 ROKU W EDUKACJI HISTORYCZNEJ}

Szkolna edukacja historyczna w okresie Polski Ludowej była skutecznym narzędziem w realizacji bieżącej polityki państwa. Obraz historii Polski, w tym szczególnie najnowszej, był zniekształcony i uproszczony ${ }^{89}$. Na potrzeby artykułu przedmiotem analizy uczyniono obowiązujące $\mathrm{w}$ polskiej edukacji historycznej podręczniki ${ }^{90}$ stanowiące najważniejszy i systematycznie używany środek dydaktyczny w szkole.

Zwięzłe informacje o kampanii polskiej zostały wprowadzone do szkolnej edukacji historycznej już w 1948 roku. Wówczas, podobnie jak w historiografii, skupiono uwagę na błędach ówczesnego rządu polskiego, który ,[...] szerzył złudzenia, że armia polska jest jedną z najlepszych w Europie” oraz ,[...] nie starał się [...] zapewnić sobie pomocy Związku Radzieckiego"91. Dobrze uzbrojonej armii niemieckiej przeciwstawiono bohaterstwo żołnierzy polskich, ,[...] którzy jednak nie mogli stawić jej skutecznego oporu”. Przypomniano, że pomoc Anglii ani Francji „nie nadeszła”"92.

Język wykładu zaostrzył się w podręcznikach z lat 50. XX wieku. Od tej pory, zgodnie $\mathrm{z}$ trendem panującym $\mathrm{w}$ historiografii, o przegraną kampanię polską oskarżano wyłącznie rząd sanacyjny ${ }^{93}$. Nazywano go, zgodnie z nomenklaturą, którą zastosowano już w 1944 roku w Manifeście PKWN ${ }^{94}$, „faszystowskim” i zarzucano $\mathrm{mu}, \dot{z} \mathrm{e},[\ldots]$ odrzucił wszelkie propozycje pomocy, ofiarowanej w marcu i czerwcu 1939 roku przez Związek Radziecki”' ${ }^{95}$. Dodawano, bez skrupułów, że tym samym

${ }^{89}$ Szerzej zob. m.in. A. Młynarczyk-Tomczyk, Edukacja historyczna w liceach pedagogicznych (1944-1970). Teoria i praktyka, Kielce 2009, s. 33-133; eadem, Obchody „Polskiego Tysiaclecia” (1957-1966/67), Kielce 2019, s. 373-418.

90 Zagadnieniem „kampanii wrześniowej” na kartach międzynarodowych podręczników do nauczania historii wydanych do 2000 r. zajął się Adam Suchoński. Zob. A. Suchoński, Kampania wrześniowa 1939 roku jako element obudowy dydaktycznej międzynarodowych podręczników do nauczania historii, „Wiadomości Historyczne” 2000, nr 1, s. 31-37. Autor wykazał, że informacje związane z najazdem Hitlera na Polskę w 1939 r. występowały w podręcznikach na całym świecie. Ich zakres treściowy był różny. Ibidem, s. 32.

${ }_{91}$ T. Landecki, W. Łukaszewicz, H. Wereszycki, J. Willaume, Podręcznik historii dla VIII kl. szkoty podstawowej, red. N. Gąsiorowska, Warszawa 1948, s. 392.

92 Ibidem.

${ }_{93}$ G. Missalowa, J. Schoenbrenner, Historia Polski, Warszawa 1951, s. 267.

94 Podkreślano, że rząd sanacyjny opierał się na „,bezprawnej, faszystowskiej konstytucji z kwietnia 1935 r.”, Manifest Polskiego Komitetu Wyzwolenia Narodowego, „Rocznik Lubelski” 1959, nr 2, s. 7. http://bazhum.muzhp.pl/media//files/Rocznik_Lubelski/Rocznik_Lubelski- r1959- t2/Rocznik_Lubelski-r1959-t2-s7-14/Rocznik_Lubelski-r1959-t2-s7-14.pdf.

${ }^{95}$ G. Missalowa, J. Schoenbrenner, Historia Polski, s. 267. 
„Pozbawił [...] naród polski jedynej realnej pomocy, jaką chciał mu okazać Związek Radziecki [...]. Brnął dalej po drodze zdrady narodowej, pchając kraj do zguby" ${ }^{\prime 96}$. O pakcie Ribbentrop-Mołotow nie wspomniano ${ }^{97}$. Na tle nowocześnie uzbrojonych i zmotoryzowanych wojsk hitlerowskich przedstawiono stanowisko „reakcyjnego rządu”, przekłamując historię, że już „w pierwszych dniach najazdu opuścił kraj”"98. Tylko - jak podkreślano - wojsko, wspierane przez masy ludowe, pozbawione kierownictwa i broni walczyło po bohatersku ${ }^{99}$.

Szczególną rolę, czyniąc ukłon wobec Związku Radzieckiego, przypisano komunistom polskim, którzy ,[...] wyłamywali kraty więzienia i stanęli w szeregach obrońców Ojczyzny" ${ }^{100}$. Do roli bohatera narodowego urósł Marian Buczek ${ }^{101}$. O samej kampanii polskiej 1939 roku pisano niewiele. Wspomniano o załodze Westerplatte, o obronie Helu, o krwawej bitwie pod Kutnem i obronie Warszawy ${ }^{102}$. Dzień 17 września, zgodnie $\mathrm{z}$ historiograficznym przekazem, został przedstawiony w tendencyjny sposób: „17 września 1939 roku Armia Czerwona wkroczyła do Zachodniej Białorusi i Zachodniej Ukrainy i zajęła je. Ziemie te, wyzwolone z ucisku narodowego, jaki cierpiały pod panowaniem burżuazji polskiej, zjednoczyły się znów z Radziecką Białorusią i Radziecką Ukrainą" ${ }^{103}$. Tendencyjnie przedstawiono również przyczyny klęski wrześniowej. Jak przekonywano uczniów: „Imperialistyczna Rzeczpospolita przestała istnieć. Winę za jej klęskę ponoszą klasy rządzące, obszarnicy i burżuazja, zdradzająca co krok interes narodu dla swoich egoistycznych interesów klasowych [...]"104.

Taki obraz kampanii polskiej 1939 roku funkcjonował, zgodnie z hasłami zawartymi w programie do szkoły podstawowej z lat $60 .{ }^{105}$, również w podręcznikach z tego okresu $^{106}$. Do wykładu dodano tylko informacje o celach i sensie układu Ribbentrop-Mołotow, które podawano jednak w sposób zakłamany. Pakt określony został jako ten, który był potrzebny Związkowi Radzieckiemu, aby „[...] lepiej przygotować się do nieuniknionej w przyszłości wojny z Niemcami”"107. Po raz pierwszy kampania

\footnotetext{
96 Ibidem.

97 Ibidem.

98 Ibidem.

99 Ibidem, s. 268.

100 Ibidem, s. 269.

101 Ibidem.

102 Ibidem, s. 268.

103 Ibidem, s. 270.
}

104 Ibidem, s. 269. Warto podkreślić, że podobne, choć znacznie rozbudowane treści dotyczące kampanii polskiej 1939 r. można było odnaleźć w podręczniku dla szkół średnich, Historia Polski 18641945. Materiaty do nauczania w klasie XI, pod red. Ż. Kormanowej, Warszawa 1952. Szerzej na temat tego kompendium zob. J. Rulka, Podręcznik hańby, „Wiadomości Historyczne” 1999, nr 5, s. $289-298$. W publikacji tej język wykładu był wulgarny, zwłaszcza w stosunku do rządu polskiego. Historia Polski 1864-1945, s. 417, 422, 424.

105 Program nauczania ośmioklasowej szkoły podstawowej, Warszawa 1964, s. 280; Program nauczania liceum ogólnoksztatcącego klasy I-IV, Warszawa 1966, s. 159.

106 H. Sędziwy, Historia dla klasy VIII, Warszawa 1966.

107 Ibidem, s. 152. 
wrześniowa została omówiona szczegółowo. Wspomniano o Gdańsku, Westerplatte, o chlubnym udziale marynarki wojennej ${ }^{108}$.

Obraz września 1939 roku, jaki usankcjonował się w latach 50. i 60. XX wieku, funkcjonował też w latach $70 .{ }^{109}$ Dopiero w okresie fermentu politycznego lat 80 . nieco złagodzono w podręcznikach tendencyjny obraz wydarzeń z września i października 1939 roku. Autor podręcznika z tego okresu, Andrzej Leszek Szcześniak ${ }^{110}$, mógł już więcej napisać o żądaniach Niemiec wobec Polski jako konsekwencji ustępstw państw zachodnich wobec zaborczej polityki Hitlera, a nie, jak dotąd, skupiać uwagę tylko na błędach w polityce zagranicznej sanacji ${ }^{111}$. Wyciszono propagandowe hasła o faszystowskiej postawie rządu polskiego, wskazywano natomiast na jednoznaczną i stanowczą odpowiedź Polski na żądania niemieckie ${ }^{112}$. Do obiektywizmu zbliżał się również przekaz dotyczący niemiecko-radzieckiego paktu o nieagresji, który, jak słusznie skonkludowano, rozgraniczał „strefy interesów w Europie” ${ }^{113}$. Wyposażonej w najnowocześniejszy sprzęt bojowy armii hitlerowskiej przeciwstawiono bardzo nikłe możliwości Polski w tym zakresie ${ }^{114}$. Szczegółowo omówiono „wojnę obronną” Polski we wrześniu 1939 roku. Wspomniano nawet - po raz pierwszy - o bitwie pod Lwowem ${ }^{115}$. O 17 września napisano krótko: „,17 września o godzinie 3.00 rano wojska radzieckie weszły na obszary wschodnie II RP” ${ }^{116}$. W zagadnieniu „historia osądzi" przywołano fakt opuszczenia terytorium RP przez rząd polski ${ }^{117}$.

W podręczniku dla szkół średnich więcej miejsca poświęcono sytuacji międzynarodowej Polski w przededniu II wojny światowej ${ }^{118}$. Novum stanowiła również informacja o polskich przygotowaniach obronnych do „odparcia agresji” ${ }^{119}$ i o koncepcji wojny z Niemcami, która „oparła się na założeniach czynnej pomocy wojskowej państw sojuszniczych" ${ }^{20}$. Przypomnijmy, że dotąd dominowała krytyczna ocena rządu sanacyjnego. Po raz pierwszy wspomniano też o polskim planie wojskowym „Z” (polegającym na rozmieszczeniu armii polskich na głównej linii obrony biegnącej wzdłuż granicy z Niemcami i Słowacją), i o tym, że miał on wyraźnie polityczny, nie wojskowy, charakter. Podkreślano, czyniąc ukłon w stronę ówczesnego rządu

108 Ibidem, s. 155.

${ }^{109}$ H. Sędziwy, Historia dla kl. XI, cz. 2, Warszawa 1965, s. 153-161; A.L. Szcześniak, Historia dla klasy VIII, Warszawa 1976. W podręczniku z lat 70. podano jednak dużo więcej informacji na temat wojny obronnej Polski we IX 1939 r. A.L. Szcześniak, Historia dla klasy VIII, s. 112-123.

${ }_{110}$ A.L. Szcześniak, Historia. Polska i świat naszego wieku lata 1918-1939. Książka pomocnicza dla klasy ósmej szkoły podstawowej. Wydanie drugie poprawione, Warszawa 1986.

111 Ibidem, s. 136.

112 Ibidem, s. 137.

113 Ibidem, s. 140.

114 Ibidem, s. 141.

115 A.L. Szcześniak, Polska i świat naszego wieku od roku 1939. Książa pomocnicza dla klasy ósmej szkoły podstawowej, wyd. 3, Warszawa 1989, s. 5-20.

${ }^{116}$ Ibidem, s. 13.

117 Ibidem, s. 15.

${ }_{118}$ T. Siergiejczyk, Dzieje najnowsze 1939-1945. Historia dla szkót średnich (klasa IV Liceum Ogólnoksztatcacego oraz klasa III technikum i liceum zawodowego), Warszawa 1986, s. 11-14.

119 Ibidem, s. 15.

${ }^{120}$ Ibidem, s. 16. 
polskiego, że „oddanie bez walki zachodniej części Polski byłoby katastrofą polityczną i oznaczałoby przegranie wojny już z chwilą jej rozpoczęcia"121. Oskarżenie rządu sanacyjnego o klęskę w czasie wojny, o nieracjonalną i skierowaną przeciwko ZSRR politykę zagraniczną znacznie wyciszono na rzecz przedstawienia planu przygotowania Polski do wojny i realnych koncepcji politycznych i militarnych jej obrony ${ }^{122}$.

Wspomniano również o jedności społeczeństwa polskiego wobec zagrożenia niepodległości ${ }^{123}$, ale - tak jak do tej pory - nie zapomniano też o komunistach „manifestujących swój patriotyzm" (samego Buczka jednak nie przywołano) ${ }^{124}$. Na 16 stronach opisano „kampanię wrześniową" ${ }^{25}$. Inaczej niż dotychczas odniesiono się do wydarzeń z 17 września 1939 roku. Przedstawiono je, przybliżając się coraz bardziej do prawdy, jako wkroczenie Armii Czerwonej, ,[...] które wprowadziło do wojny obronnej nową sytuację polityczną" ${ }^{26}$ i zostało „boleśnie” przyjęte przez znaczne kręgi polskiego społeczeństwa, jako akt „,nieprzyjazny” ${ }^{27}$.

Lata 90. XX wieku przyniosły w edukacji historycznej dalsze pogłębienie wiedzy o kampanii polskiej 1939 roku $^{128}$. Starano się w podręcznikach w większym zakresie zobrazować uczniom trudne położenie rządu polskiego, a także jego wysiłki włożone w obronę kraju ${ }^{129}$. Również o pakcie Ribbentrop-Mołotow i dołączonym do niego tajnym protokole napisano wprost jako o dokumencie ustalającym strefy wpływów w Europie Środkowej obu totalitarnych reżimów ${ }^{130}$. W negatywnym świetle ukazano zabiegi dyplomatów zachodnich wobec roszczeń niemieckich i to im przypisano winę za przesunięcie terminu mobilizacji powszechnej w Polsce na 31 sierpnia 1939 roku $^{131}$. „Wojnę obronną Polski” w 1939 roku omówiono bardzo szczegółowo ${ }^{132}$.

O 17 września napisano już obiektywnie jako o ,wkroczeniu wojsk sowieckich na ziemie Rzeczypospolitej”, której celem było „szybkie opanowanie wschodnich województw Polski $[\ldots]$.. "133. Dokonano również oceny września. Zamiast treści o archaicznym sposobie prowadzenia wojny przypominano o rzeczywistych możliwościach obronnych Polski ${ }^{134}$. Podobny obraz wydarzeń z września 1939 roku można odnaleźć w obowiązującym w tym samym czasie podręczniku dla szkół średnich ${ }^{135}$.

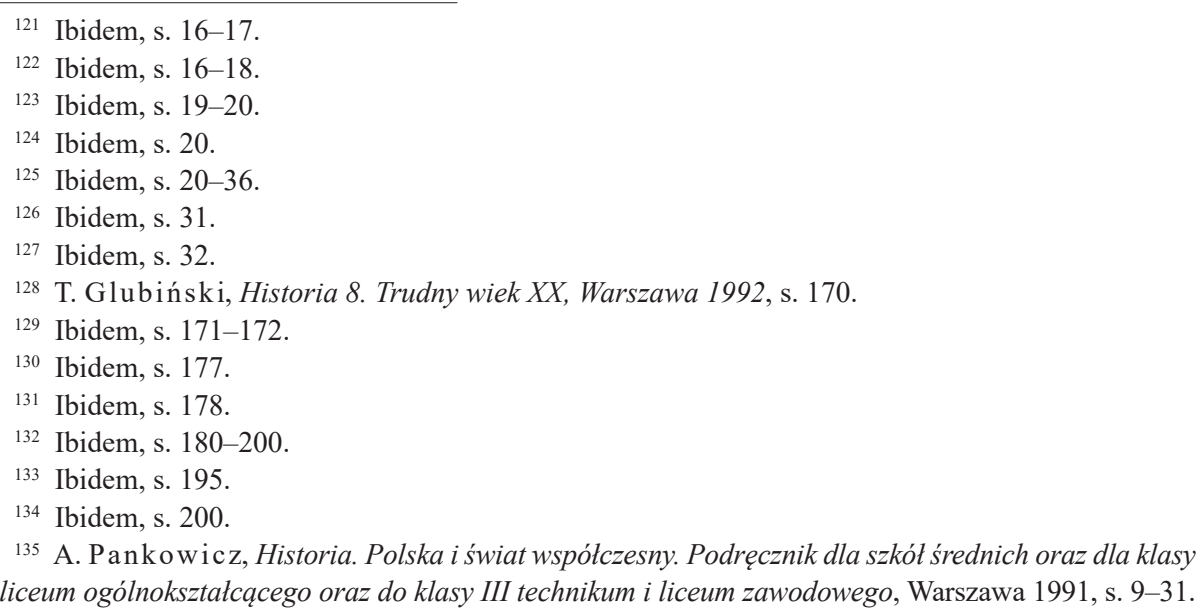


Rok 1989 stanowił niewątpliwie przełomową datę dla szkolnego przekazu historycznego, w tym dotyczącego obrazu kampanii polskiej 1939 roku. Dyskontynuacja przejawiała się przede wszystkim w docenieniu wysiłku zbrojnego dowództwa i sił politycznych, które zastosowało realną koncepcję obrony kraju. Wszakże czekano na pomoc państw sojuszniczych, która nie nadeszła. Młodzież mogła również dowiedzieć się prawdy o znamiennej dacie 17 września 1939 roku. Kontynuacja to przede wszystkim docenienie wysiłku polskiego żołnierza i obywateli w obronę ojczyzny.

Co przyniósł XXI wiek w edukacji historycznej? Niewątpliwie problematyka ta wymaga dogłębnego zbadania. Warto jednak wskazać na drastyczną, zwłaszcza w pierwszej dekadzie XXI wieku, redukcję treści kształcenia z zakresu wojny i okupacji ${ }^{136}$. Dopiero przeniesienie w 2012 roku $^{137}$ treści z zakresu historii najnowszej na czwarty etap edukacyjny spowodowało, przynajmniej w szkole średniej, ponowną rozbudowę materiału z zakresu II wojny światowej (kampania polska 1939 roku przedstawiona była jako jej pierwszy etap) ${ }^{138}$.

Ostatnia reforma programowa, która jest realizowana w Polsce od 1 września 2017 roku $^{139}$, wprowadziła treści kształcenia z zakresu historii najnowszej do klasy siódmej i ósmej. Zostały one znacząco rozbudowane, wydaje się, że ze szkodą dla młodzieży 13-,14-letniej, nastawionej w XXI wieku na wielostronny transfer wiedzy historycznej ${ }^{140}$. Uczeń jest wyposażony w obszerną wiedzę dotyczącą polskiej kampanii 1939 roku. Obronę Polski w 1939 roku wymiennie nazywa się „kampanią polską" i „wojną obronną", a jej klęski, podobnie jak w historiografii, doszukuje się w zbyt późnej powszechnej mobilizacji i dysproporcjach sił ${ }^{141}$.

${ }^{136}$ Rozporządzenie MEN z dn. 26 II 2002 r. w sprawie podstawy programowej wychowania przedszkolnego oraz kształcenia ogólnego w poszczególnych typach szkół; Rozporządzenie MEN z dn. 23 XII 2008 r. w sprawie podstawy programowej wychowania przedszkolnego oraz kształcenia ogólnego w poszczególnych typach szkół, https://www.librus.pl/doradca- dyrektora/pytania- i- odpowiedzi/nowa- i- stara- podstawa-programowa/ [dostęp: 17 IX 2019 r.]; K. Zielińska, D. Kołodziejczyk, Poznajemy dzieje cywilizacji. Podręcznik dla klasy 5 szkoty podstawowej, Warszawa 2003, s. 193; G. Woj cie chow ski, Dzień dobry historio! Podręcznik do historii i społeczeństwa dla klasy 6, Warszawa 2010, s. 190-196; B. Burda, B. Halczak, R.M. Józefiak, M. Szymczak, Historia najnowsza. Historia 3. Zakres rozszerzony. Podręcznik dla liceum ogólnokształcacego, Gdynia 2005, s. 133-137.

${ }^{137}$ Rozporządzenie MEN z dn. 27 VIII 2012 r. w sprawie podstawy programowej wychowania przedszkolnego oraz kształcenia ogólnego w poszczególnych typach szkół, https://www.librus.pl/doradca- dyrektora/pytania- i- odpowiedzi/nowa- i- stara- podstawa- programowa/ [dostęp: 17 IX 2019 r.].

${ }_{138}$ Rozporządzenie MEN z dn. 23 XII 2008 r., s. 137; http://prawo.sejm.gov.pl/isap.nsf/download. xsp/WDU20120000977/O/D20120977.pdf [dostęp: 17 IX 2019 r.]; S. Roszak, J. Kłaczkow, Poznać przeszłość. Wiek XX. Zakres podstawowy. Podręcznik do historii dla szkót ponadgimnazjalnych klasa I, Warszawa 2011, s. 124-131; J. Kłaczkow, A. Zielińska, Zrozumieć przeszłość. Dzieje najnowsze po 1939 r. Podręcznik do historii dla liceum ogólnoksztatcacego i technikum. Cz. 4. Zakres rozszerzony, Warszawa 2015, s. 6-15.

$139 \mathrm{https} / / / \mathrm{men} . g o v \cdot p l /$ ministerstwo/informacje/nowa-podstawa-programowa-dla-liceum-technikum-i- branzowej-szkoly-ii-stopnia-podpisana.html [dostęp: 17 IX 2019 r.].

140 https://podstawaprogramowa.pl/Szkola- podstawowa- IV-VIII/Historia [dostęp: 17 IX 2019 r.]; J. Kłaczkow, A. Łaszkiewicz, S. Roszak, Wczoraj i dziś. Podręcznik do historii dla klasy siódmej szkoty podstawowej, Warszawa 2017, s. 264-267; R. Śniegocki, A. Zielińska, Wczoraj i dziś. Podręcznik dla klasy 8 szkoły podstawowej, Warszawa 2018, s. 11-14.

${ }^{141}$ R. Śniegocki, A. Zielińska, Wczoraj i dziś, s. 11-14; S. Roszak, J. Kłaczkow, Poznać przeszłość, s. 124-131; J. Kłaczkow, A. Zielińska, Zrozumieć przeszłość, s. 6-15. 


\section{PODSUMOWANIE}

Kampania polska 1939 roku zajęła i zajmuje szczególne miejsce w dorobku historiograficznym i szkolnej edukacji historycznej. O nią toczą się nieustannie, niewątpliwie potrzebne w nauce historycznej, spór terminologiczny i polemika wokół ocen. Przekaz naukowy i popularnonaukowy były i pozostają kompatybilne. W pewnych momentach, zwłaszcza w okresie szturmu ideologicznego z lat 50. XX wieku, edukacja historyczna wyprzedzała ustalenia historiografii, kreując obraz antyniemiecki i proradziecki. Bardzo krytycznie, bez kontekstu międzynarodowego, oceniano również rząd polski, który sprawował władzę w momencie niemieckiej agresji na Polskę. To jego oskarżono o klęskę. Chociaż po 1989 roku narracja dotycząca kampanii polskiej 1939 roku została istotnie zmieniona i uzupełniona, na przykład o rzetelne informacje dotyczące 17 września 1939 roku, to nadal znajduje się pod silnym oddziaływaniem politycznym.

Wrzesień 1939 roku, jak słusznie zauważył Jacek Chrobaczyński, powinien pozostać przede wszystkim jedną z najważniejszych dat w naszej historii. Był bowiem „zbiorowym doświadczeniem wielomilionowego narodu, doświadczeniem niebywale dramatycznym, a wiedza o nim była i pozostaje pewnego rodzaju zbiorową kliszą pamięci, co roku przypominaną, pomimo zróżnicowanej rzeczywistości: wojennej, PRL-owskiej czy współczesnej”'142. Kampania polska i jej rocznice powinny przestrzegać społeczeństwo przed wojną jako sposobem rozwiązywania konfliktów. Nie było to jednak możliwe, gdy dominował propagandowy język i jednostronny przekaz, jak to było w okresie PRL. Nie jest to również wykonalne ani przy znacząco ograniczonym przekazie dotyczącym tych wydarzeń, jakim w szkolonej edukacji historycznej charakteryzowała się pierwsza dekada XXI wieku, ani przy nadmiernej rozbudowie treści, jaką cechują ostatnie reformy programowe. W pierwszym przypadku młode pokolenie Polaków, dla których kampania polska powinna być szczególnie ważna, wiedziało zbyt mało o okrucieństwach wojny. Obecnie natomiast, ze względu na nadmiar faktów i dat, może zniechęcić do głębszej refleksji.

\section{BIBLIOGRAFIA}

Bartkowski Z., Pogoda września a wojna obronna Polski, „Przegląd Geofizyczny” 1999, z. 3, s. 153-161.

Bartoszewski W., Słowo wstępne [w:] M. Getter, Wrzesień 1939 w książce, prasie i filmie. Poradnik bibliograficzny, słowo wstępne napisał W. Bartoszewski, Warszawa 1964, s. 2-3.

Burda B., Halczak B., Józefiak R.M., Szymczak M., Historia najnowsza. Historia 3. Zakres rozszerzony. Podręcznik dla liceum ogólnoksztatcącego, Gdynia 2005.

${ }^{142}$ J. Chrobaczyński, op. cit., s. 155. 
Chrobaczyński J., „Nie okryt się niesława naród polski”. Społeczne aspekty września 1939 roku, Kraków 2002.

Getter M., Wrzesień 1939 w książce, prasie i filmie. Poradnik Bibliograficzny, słowo wstępne napisał W. Bartoszewski, Warszawa 1964.

Glubiński T., Historia 8. Trudny wiek XX, Warszawa 1992.

Górecki D., Pozycja ustrojowo-prawna Prezydenta Rzeczypospolitej i rzadu w ustawie konstytucyjnej z 23 kwietnia 1935 roku, Łódź 1992.

Grzelak C., Kampania polska 1939 roku. Początek II wojny światowej, Warszawa 2005.

Grzelak C., Kampania polska 1939 roku w ojczystej historiografii, „Bellona” 2016, nr 4, s. $136-148$.

Grzelak C., Kozłowski E., Polski wrzesień 1939. Początek drogi w obronie wolności i niepodległości, Warszawa 1994.

Grzywacz A., Wojna obronna Polski 1939 roku w relacji polskiego sztabowca, „Zeszyty Historyczne" 1997, z. 121, s. 3-22.

Jurga T., Wojna obronna Polski w 1939 r. [w:] Wojna i okupacja na ziemiach polskich, red. W. Góra, Warszawa 1984, s. 7-34.

Kącka K., „,Mapa pamięci”. Jak upamiętnia się w Polsce II wojnę światowa, „Wiadomości Historyczne z Wiedzą o Społeczeństwie" 2017, nr 3, s. 4-10.

Kersten K., Pisma rozproszone, wybór i przygotowanie do druku T. Szarota, D. Libionka, Toruń 2005.

Kirchmayer J., Kampania wrześniowa, Warszawa 1946.

Kłaczkow J., Łaszkiewicz A., Roszak S., Wczoraj i dziś. Podręcznik do historii dla klasy siódmej szkoty podstawowej, Warszawa 2017.

Kłaczkow J., Zielińska A., Zrozumieć przeszłość. Dzieje najnowsze po 1939 r. Podręcznik do historii dla liceum ogólnoksztatcąego i technikum. Cz. 4. Zakres rozszerzony, Warszawa 2015.

Landecki T., Łukaszewicz W., Wereszycki H., Willaume J., Podręcznik historii dla VIII klasy szkoły podstawowej, red. N. Gąsiorowska, Warszawa 1948.

Missalowa G., Schoenbrenner J., Historia Polski, Warszawa 1951.

Majchrowski J. M., Wstęp [w:] Stanisław Car. Polska koncepcja autorytaryzmu, wstęp i wybór J.M. Maj chrowski, Warszawa 1996.

Miśkiewicz B., Studia z dziejów polskiej historiografii wojskowej, t. 1, red. B. Miśkiewicz, Poznań 1975.

Młynarczyk-Tomczyk A., Edukacja historyczna wliceach pedagogicznych (1944-1970). Teoria i praktyka, Kielce 2009.

Młynarczyk-Tomczyk A., Obchody „Polskiego Tysiąclecia” (1957-1966/67), Kielce 2019.

Moczulski L., Wojna polska: rozgrywka dyplomatyczna $w$ przededniu wojny $i$ działania obronne we wrześniu-październiku 1939, Poznań 1972; Lublin 1990.

Moczulski L., Wojna polska, Warszawa 2009.

Ney-Krwawicz M., Wrzesień 1939 roku w historiografii polskiej ostatniego dwudziestolecia [w:] Spojrzenie na polski wrzesień, red. T. Kondracki, Warszawa 2011.

Pankowicz A., Historia. Polska i świat współczesny. Podręcznik dla szkót średnich oraz dla klasy IV liceum ogólnokształcącego oraz do klasy III technikum i liceum zawodowego, Warszawa 1991.

Pło ski S., Generał Jerzy Kirchmayer, „Najnowsze Dzieje Polski. Materiały i studia z okresu II wojny światowej” 1959, t. 3.

Program nauczania liceum ogólnoksztatcącego klasy I-IV, Warszawa 1966.

Program nauczania ośmioklasowej szkoty podstawowej, Warszawa 1964.

Putrament J., Wrzesień. Powieść, Warszawa 1953. 
Rawski T., Stąpor Z., Zamoj ski J., Wojna wyzwoleńcza narodu polskiego w latach 1939 1945. Węzłowe problemy, Warszawa 1963.

Rezmer W., Problem terminologiczny: kampania wrześniowa - wojna obronna Polski kampania polska, „Przegląd Historyczno-Wojskowy” 2009, R. 10, nr 3, s. 117-124.

Romek Z., Cenzura w PRL, Analiza zjawiska, red. Z. Romek, K. Kamińska-Chełmniak, Warszawa 2017.

Romek Z., Cenzura a nauka historyczna w Polsce 1944-1970, Warszawa 2010.

Roszak S., Kłaczkow J., Poznać przeszłość. Wiek XX. Zakres podstawowy. Podręcznik do historii dla szkół ponadgimnazjalnych klasa I, Warszawa 2011.

Ruchniewicz K., Pamięć historyczna Polaków, „Śląski Kwartalnik Historyczny Sobótka” 2005, nr 2, s. 207-228.

Rulka J., Podręcznik hańby, „Wiadomości Historyczne” 1999, nr 5.

Sędziwy H., Historia dla kl. XI, cz. 2, Warszawa 1965.

Sędziwy H., Historia dla klasy VIII, Warszawa 1966.

Siergiejczyk T., Dzieje najnowsze 1939-1945. historia dla szkót średnich (klasa IV liceum ogólnokształcącego oraz klasa III technikum i liceum zawodowego), Warszawa 1991.

Si ergiejczyk T., Dzieje najnowsze 1939-1945. historia dla szkót średnich (klasa IV liceum ogólnokształcącego oraz klasa III technikum i liceum zawodowego), Warszawa 1986.

Stawecki P., Jeszcze raz w sprawie określenia ,wojna obronna Polski 1939”, „Przegląd Historyczno-Wojskowy" 2010, nr 1, s. 161-168.

Staw ecki P., W sprawie terminu „, wojna obronna Polski”, „Przegląd Historyczno-Wojskowy" 2007, nr 1, s. 204-207.

Stobiecki R., Historycy wobec polityki historycznej [w:] Pamięć i polityka historyczna. Doświadczenia Polski i jej sąsiadów, red. S.M. Nowinowski, J. Pomorski, R. Stobiecki, Łódź 2008.

Suchoński A., Kampania wrześniowa 1939 roku jako element obudowy dydaktycznej międzynarodowych podręczników do nauczania historii, „Wiadomości Historyczne” 2000, nr 1, s. 31-37.

Szcześniak A.L., Historia dla klasy VIII, Warszawa 1976.

Szcześniak A.L., Polska i świat naszego wieku od roku 1939. Książka pomocnicza dla klasy 8 szkoty podstawowej, wyd. 3, Warszawa 1989.

Śniegocki R., A. Zielińska A., Wczoraj i dziś. Podręcznik dla klasy 8 szkoły podstawowej, Warszawa 2018.

Tarnopolski M., Kampania Wrześniowa 1939. Ze wspomnień dowódcy plutonu 15 Pułku Ułanów Poznańskich. Cz. 1-2, „Przegląd Kawalerii i Broni Pancernej” 1989, nr 131, s. 10-21; nr 133, s. 309-317.

Woj ciechowski G., Dzień dobry historio! Podręcznik do historii i społeczeństwa dla klasy 6, Warszawa 2010.

Wojna obronna Polski w 1939 r. Bibliografia za lata 1985-1989, , t. 1-3, oprac. W. Henzel, I. Sawicka, Warszawa 1992.

Wojna obronna Polski 1939 r. Polski Czyn zbrojny w II wojnie światowej, oprac. M. Cieplewicz, T. Jurga, E. Kozłowski [et al.], red. E. Kozłowski, Warszawa 1979.

Zielińska K., Kołodziejczyk D., Poznajemy dzieje cywilizacji. Podręcznik dla klasy 5 szkoły podstawowej, Warszawa 2003. 


\section{Źródła internetowe}

https://men.gov.pl/ministerstwo/informacje/nowa-podstawa-programowa-dla-liceum-technikum-i-branzowej-szkoly-ii-stopnia-podpisana.html [dostęp: 17 IX 2019 r.].

https://podstawaprogramowa.pl/Szkola-podstawowa-IV-VIII/Historia [dostęp: 17 IX 2019 r.]. http://prawo.sejm.gov.pl/isap.nsf/download.xsp/WDU20120000977/O/D20120977.pdf [dostęp: 17 IX 2019 r.].

https://www.librus.pl/doradca-dyrektora/pytania-i-odpowiedzi/nowa-i-stara-podstawa-programowa [dostęp: 17 IX 2019 r.].

Manifest Polskiego Komitetu Wyzwolenia Narodowego, „Rocznik Lubelski” 1959, nr 2, s. 7, http://bazhum.muzhp.pl/media//files/Rocznik_Lubelski/Rocznik_Lubelski-r1959-t2/Rocznik_Lubelski-r1959-t2-s7-14/Rocznik_Lubelski-r1959-t2-s7-14.pdf [dostęp: 10 IX 2019 r.]. Męczykowski Ł., ,, Wojna polska 1939” - recenzja i ocena, https://histmag.org/Leszek-Moczulski-Wojna-polska-1939-recenzja-3797/ [dostęp: 15 V 2020 r.].

https://www.biblionetka.pl/book.aspx?id=81457 [dostęp: 15 V 2020 r.]. 